Article

\title{
Delayed Formation of Thermally Grown Oxide in Environmental Barrier Coatings for Non-Oxide Ceramic Matrix Composites
}

\author{
Hagen Klemm *, Katrin Schönfeld ${ }^{D}$ and Willy Kunz \\ Fraunhofer Institute for Ceramic Technologies and Systems IKTS, Dresden 01277, Germany; \\ katrin.schoenfeld@ikts.fraunhofer.de (K.S.); willy.kunz@ikts.fraunhofer.de (W.K.) \\ * Correspondence: hagen.klemm@ikts.fraunhofer.de; Tel.: +49-351-2553-7553
}

Received: 22 November 2019; Accepted: 17 December 2019; Published: 19 December 2019

check for updates

\begin{abstract}
The oxidation and corrosion behavior at elevated temperatures of a $\mathrm{SiC}_{\mathrm{F}} / \mathrm{SiC}(\mathrm{N})$ composite with two plasma-sprayed environmental barrier coating (EBC) systems were studied. After both processes, the formation of a silica-based thermally grown oxide (TGO) layer was observed. The formation of this TGO caused two principal failure mechanisms of the EBC. Firstly, spallation of the EBC induced by stresses from volume expansion and phase transformation to crystalline $\mathrm{SiO}_{2}$ was observed. Water vapor corrosion of the TGO with gap formation in the top region of the TGO was found to be a second failure mechanism. After a burner rig test of the $\mathrm{Al}_{2} \mathrm{O}_{3}-\mathrm{YAG}$ EBC system, this corrosion process was observed at the TGO surface and in the volume of the $\mathrm{Al}_{2} \mathrm{O}_{3}$ bond coat. In the case of the second system, $\mathrm{Si}-\mathrm{Yb}_{2} \mathrm{Si}_{2} \mathrm{O}_{7} / \mathrm{SiC}-\mathrm{Yb}_{2} \mathrm{SiO}_{5}$, the formation of the TGO could be delayed by introducing an additional intermediate layer based on $\mathrm{Yb}_{2} \mathrm{Si}_{2} \mathrm{O}_{7}$ filled with $\mathrm{SiC}$ particles. The SiC particles in the intermediate layer were oxidized and served as getter to reduce the permeation of oxidants $\left(\mathrm{O}_{2}, \mathrm{H}_{2} \mathrm{O}\right)$ into the material. In this way, the formation of the TGO and the failure mechanisms caused by their formation and growth could be delayed.
\end{abstract}

Keywords: environmental barrier coatings; non-oxide ceramic matrix composites; oxidation; water vapor corrosion; thermally grown oxide; damage mechanisms

\section{Introduction}

Silicon carbide fiber-based ceramic matrix composites (CMCs) offer a high potential for applications as structural components in advanced gas turbines. In comparison to metallic super alloys, used in the state of the art, the main advantages of these materials were found to be their low specific weight in combination with a superior potential at elevated temperatures up to $1400{ }^{\circ} \mathrm{C}$. Furthermore, among ceramic materials, CMCs are characterized by a damage-tolerant fracture behavior, suggesting them as promising candidates for gas turbine applications as well. During recent years, significant progress has been achieved in material development and processing. However, there are still considerable deficits at present, especially in the long-term behavior of the composites in hot gas atmosphere. Corrosion processes were observed, caused by the high water vapor pressure in combination with high temperatures and gas velocities. The resulting microstructural and mechanical degradation of the composites and the damage mechanisms of these processes have been described in several studies [1-6]. Volatilization of the protective silica-based surface layer by the formation and evaporation of silicon hydroxides $\left(\mathrm{Si}(\mathrm{OH})_{4}\right)$ was found to be the main process leading to considerable material loss with recession rates in the range of $1 \mu \mathrm{m} / \mathrm{h}$ (Equation (1)). Additional material degradation as a consequence of oxidation processes inside the composite was observed.

$$
\mathrm{SiO}_{2}+2 \mathrm{H}_{2} \mathrm{O}_{(\mathrm{g})}=\mathrm{Si}(\mathrm{OH})_{4(\mathrm{~g})}
$$


Environmental barrier coatings (EBCs) have been the solution to prevent the surface corrosion of the ceramic materials in gas turbine atmospheres $[7,8]$. During the last few years, different EBC systems have been introduced [8-10]. As a consequence of the complex conditions during operation at elevated temperatures in a hot gas atmosphere, multilayer coatings with special functions were proposed. In this way, several features required to guarantee the long-term stability of the EBC system in hot gas conditions could be realized.

Beside their stability against erosion, interaction with Ca-Mg-Al-silicates (CMAS), or foreign object damage, the top layer of the system must primarily exhibit a superior water vapor corrosion stability. During recent years, several oxide systems with superior corrosion stability have been suggested to protect non-oxide ceramics or CMCs based on $\mathrm{Si}_{3} \mathrm{~N}_{4}$ or $\mathrm{SiC}$ against water vapor corrosion [11,12]. Among these oxide systems, rare-earth (RE) silicates have been identified as promising EBC candidates for top layer materials. While the RE-monosilicates are mostly stable in a hot gas environment, the disilicates were found to be partially volatilized with the formation of silicon hydroxide and the more stable monosilicate (Equation (2)) [8,12-17].

$$
\mathrm{RE}_{2} \mathrm{Si}_{2} \mathrm{O}_{7}+2 \mathrm{H}_{2} \mathrm{O}_{(\mathrm{g})}=\mathrm{RE}_{2} \mathrm{SiO}_{5}+\mathrm{Si}(\mathrm{OH})_{4(\mathrm{~g})}
$$

This corrosion process led consequently to the formation of a stable monosilicate layer, influencing the corrosion behavior of the EBC system during long-term application.

Currently, a layer based on metallic silicon is used as a very effective bond coat in several EBC systems $[18,19]$. With a melting point of about $1410{ }^{\circ} \mathrm{C}$, silicon bond coats are limited in their temperature potential. For use at lower temperatures, however, they are characterized by several benefits. First, the coatings agree well with the coefficient of thermal expansion (CTE) of the non-oxide $\mathrm{CMC}$ substrate material. The second point is the getter function of the silicon against the permeation of oxidizing compounds $\left(\mathrm{O}_{2}, \mathrm{H}_{2} \mathrm{O}\right)$ and prevention of oxidation processes inside the CMC component.

Various multilayer EBC systems with $\mathrm{Si}$ bond coats and RE-top coats were demonstrated to be quite effective in the protection of $\mathrm{SiC}_{\mathrm{F}} / \mathrm{SiC}$ CMC $[10,16,17,20,21]$. However, during operation at elevated temperatures in hot gas atmosphere, several processes led to degradation of the whole system. A summary of possible failure modes was reported by Lee [19]. Processes like the formation of stresses during thermal cycling, foreign objects, phase transformation, or sintering processes resulted in cracking, delamination, and spallation of the EBC system. Additional chemical processes like water vapor or CMAS corrosion limit the stability and functionality of the protecting system. During long-term use, oxidation processes were found to be an additional critical factor for the stability of the EBC. Diffusion of oxygen and, especially, the permeation of $\mathrm{H}_{2} \mathrm{O}$ through the different $\mathrm{EBC}$ layers are responsible for the formation of a thermally grown oxide (TGO) layer of mainly silica at the upper side of the $\mathrm{Si}$ bond coat. With growing thickness of the $\mathrm{SiO}_{2} \mathrm{TGO}$ layer, crystallization and phase transition processes (cristobalite) were observed, finally leading to stresses in the $\mathrm{EBC}$ system with the consequence of cracking and spallation of the EBC [10,16,22].

In real conditions, the formation of the TGO layer cannot be avoided. There will always be permeation of oxygen and water into the material, finally leading to oxidation processes inside. However, there are strategies to minimize the rate of TGO layer formation and their following influences. First, the transport of the oxidants $\left(\mathrm{O}_{2}\right.$ and $\left.\mathrm{H}_{2} \mathrm{O}\right)$ through the EBC system should be considered. There is still a considerable lack of data about the permeation properties (diffusion coefficient, oxidant solubility) of the various materials used in the EBC layer system. Furthermore, the morphology of the different layers, like layer thickness, porosity, crystallinity, and grain boundary structure, has to be studied regarding their influence on their permeation properties. Recently, an example in this direction was introduced by Lee [19]. The TGO growth rate in an EBC system with the $\mathrm{Si}$ bond coat and $\mathrm{Yb}_{2} \mathrm{Si}_{2} \mathrm{O}_{7}$ was found to be significantly reduced by modifying the $\mathrm{Yb}_{2} \mathrm{Si}_{2} \mathrm{O}_{7}$ layer with various oxides $\left(\mathrm{Al}_{2} \mathrm{O}_{3}\right.$, mullite, $\left.\mathrm{Y}_{3} \mathrm{Al}_{5} \mathrm{O}_{12}\right)$. As a conclusion of these results, he suggested a modification of the $\mathrm{SiO}_{2}$ network structure of the TGO by incorporating $\mathrm{Al}^{3+}$ - and $\mathrm{Yb}^{3+}$-ions, consequently leading to lower permeation rates of oxidants $\left(\mathrm{H}_{2} \mathrm{O}\right)$ through the TGO layer. 
A defined control of the oxidation and corrosion processes itself was found to be a second strategy. This can be performed by modification of the oxidation mechanism, e.g., defined reaction products or the location where the oxidation takes place. An example for such a strategy was reported for monolithic $\mathrm{Si}_{3} \mathrm{~N}_{4}$ with $\mathrm{SiC}$ or $\mathrm{MoSi}_{2}$ additions [12,23]. During oxidation of these composites, a changed oxidation mechanism with the formation of $\mathrm{Si}_{2} \mathrm{ON}_{2}$ in the top region of the bulk material was observed, leading finally to less defect formation caused by the oxidation processes in the microstructure of the material. The focus of this study was placed in a similar direction, namely, to avoid the formation of a TGO as a reaction layer at, e.g., the silicon bond coat, by a defined reaction of the permeating oxidants at other regions.

\section{Materials and Methods}

The base CMC material was fabricated by winding technology with polycrystalline SiC fibers, Tyranno SA3 (UBE Industries, Tokyo, Japan). Prior to winding, the desized SiC tows were infiltrated with an aqueous slurry composed of $\mathrm{SiC}$ powder, Sintec 15 (Saint Gobain, Courbevoie, France), and 20 vol.\% sintering additives with $\mathrm{Al}_{2} \mathrm{O}_{3}$, AKP 50 (Sumitomo Chemical, Tokyo, Japan); $\mathrm{Y}_{2} \mathrm{O}_{3}$, Grade $\mathrm{C}$ (H.C. Stark, Goslar, Germany); and $\mathrm{SiO}_{2}$, Aerosil Ox 50 (Evonic Industries, Essen, Germany). The wound cylinder ( $85^{\circ}$ winding angle) was cut and pressed, opening into a flat sheet. Matrix formation was performed in five steps of precursor infiltration and pyrolysis (PIP) with commercially available polysilazane Si-C-N precursor, HTT 1800 (Clariant Advanced Materials GmbH, Muttenz, Switzerland). Afterward, the composite was sintered at $1400{ }^{\circ} \mathrm{C}$ in nitrogen atmosphere. Finally, a $\mathrm{SiC}_{\mathrm{F}} / \mathrm{SiC}(\mathrm{N})$ composite with a fiber volume content between $40 \%$ and $50 \%$ and an open porosity of about $10 \%$ was obtained. Further details about the CMC fabrication are described in [24]. Bars with dimensions of $3 \times 10 \times 36 \mathrm{~mm}^{3}$ were used as test samples.

The first EBC system was a bond coat from $\mathrm{Al}_{2} \mathrm{O}_{3}$ with a top coat of yttrium aluminum garnet $\left(\mathrm{Y}_{3} \mathrm{Al}_{5} \mathrm{O}_{12}, \mathrm{YAG}\right)$. Both layers were fabricated by atmospheric plasma spraying. The second system was a three-layer coating system with a Si bond coat, an intermediate layer consisting of a mixture of $\mathrm{Yb}_{2} \mathrm{Si}_{2} \mathrm{O}_{7} / \mathrm{SiC}$ and $\mathrm{Yb}_{2} \mathrm{SiO}_{5}$ as the top coat. While the $\mathrm{Si}$ bond coat was fabricated by atmospheric plasma spraying (APS), the two rare-earth-containing layers were fabricated by suspension plasma spraying (SPPS). An overview of the coatings fabricated is given in Table 1:

Table 1. Average coating thickness of the layers in the two EBC systems.

\begin{tabular}{ccc}
\hline & Thickness/ $\mu \mathrm{m}$ & Fabrication \\
\hline $\mathrm{Al}_{2} \mathrm{O}_{3}-\mathrm{YAG}$ & 50 to 70 & \\
$\mathrm{Al}_{2} \mathrm{O}_{3}$ & 80 to 120 & APS \\
$\mathrm{YAG}$ & & APS \\
\hline $\mathrm{Si}-\mathrm{Yb}_{2} \mathrm{Si}_{2} \mathrm{O}_{7} / \mathrm{SiC}-\mathrm{Yb}_{2} \mathrm{SiO}_{5}$ & 30 to 50 & \\
$\mathrm{Si}$ & 100 to 150 & APS \\
$\mathrm{Yb}_{2} \mathrm{Si}_{2} \mathrm{O}_{7} / \mathrm{SiC}$ & 100 to 150 & SPPS \\
$\mathrm{Yb}_{2} \mathrm{SiO}_{5}$ & SPPS \\
\hline
\end{tabular}

Both EBC systems were tested regarding their oxidation resistance at $1200^{\circ} \mathrm{C}$ for $100 \mathrm{~h}$ in furnace air. Additionally, hot gas corrosion tests were conducted in a high-temperature burner rig at atmospheric pressure [11]. The coated test samples were blown directly by the hot gas in a reactor tube of solid-state sintered $\mathrm{SiC}$ with an inner diameter of $30 \mathrm{~mm}$. The hot gas was composed of the combustion products of natural gas in air and additional water vapor. The conditions of the corrosion tests are summarized in Table 2. Further details regarding the burner rig test are described in [11]. 
Table 2. Burner rig test performed.

\begin{tabular}{cccc}
\hline Temperature $/{ }^{\circ} \mathbf{C}$ & Flow Speed $/ \mathbf{m} / \mathbf{s}$ & Water Vapor Pressure $/$ bar & Testing Time $/ \mathbf{h}$ \\
\hline 1200 & 100 & 0.2 & 100 \\
\hline
\end{tabular}

After both tests, the microstructure of the samples was characterized by means of polished cross-sections with field-emission scanning electron microscopy (Ultra 55, Zeiss, Oberkochen, Germany). Information about the composition of the different layers after oxidation and corrosion was obtained by using energy-dispersive X-ray spectroscopy (EDX; ISIS Si (Li) detector).

\section{Results}

A summary of the weight changes of the two coating systems in comparison to the base CMC substrate without coating observed during oxidation and the burner rig test is summarized in Table 3 . A weight gain was observed for all materials investigated after both tests.

Table 3. Weight change after oxidation and burner rig test, $1200{ }^{\circ} \mathrm{C}, 100 \mathrm{~h}$. Comparison of EBC-coated systems with base ceramic matrix composites (CMC) material without EBC coating.

\begin{tabular}{ccccc}
\hline \multirow{2}{*}{ Material/EBC } & \multicolumn{2}{c}{ Oxidation } & \multicolumn{2}{c}{ Burner Rig Test } \\
& $\mathbf{m} / \mathbf{g}$ & $\mathbf{m} / \mathbf{m} / \mathbf{g} / \mathbf{g}$ & $\mathbf{m} / \mathbf{g}$ & $\mathbf{m} / \mathbf{m} / \mathbf{g} / \mathbf{g}$ \\
\hline $\mathrm{CMC}$ & 0.027 & 0.009 & 0.094 & 0.046 \\
$\mathrm{Al}_{2} \mathrm{O}_{3}-\mathrm{YAG}$ & 0.048 & 0.016 & 0.19 & 0.064 \\
$\mathrm{Si}_{-} \mathrm{Yb}_{2} \mathrm{Si}_{2} \mathrm{O}_{7} / \mathrm{SiC}^{-\mathrm{Yb}_{2}} \mathrm{SiO}_{5}$ & 0.009 & 0.003 & 0.045 & 0.016 \\
\hline
\end{tabular}

The values are the average of the three samples each. In connection with the interpretation of these results, some inaccuracies as a consequence of inhomogeneous EBC layers (thickness, pores, or cracks) should be considered. Furthermore, during the burner rig test, both processes, weight gain and weight loss, were observed. These results cannot be correlated directly with the TGO scale thickness obtained after the tests; however, some general tendencies can be followed as described in the microstructural discussion of the material investigated.

The main results were obtained by comparison of the microstructure of the CMC with different EBCs after oxidation and hot gas corrosion tests both at $1200^{\circ} \mathrm{C}$ and $100 \mathrm{~h}$. After oxidation, a weight gain was observed. During the test, oxygen diffused through the EBC layer and finally reacted at the first non-oxide surface in the system (base $\mathrm{SiC}_{\mathrm{F}}-\mathrm{SiC}(\mathrm{N})$ composite or $\mathrm{Si}$ bond coat). Usually, a TGO layer was formed. In the case of the hot gas corrosion test, a second reaction has to be considered as well. Water vapor penetrated through the EBC layer, reacted with the $\mathrm{SiO}_{2}$ of the TGO layer, and formed volatile $\mathrm{Si}(\mathrm{OH})_{4}$. As a consequence of the high gas speed, the equilibrium of the corrosion reaction in Equation (1) was strongly shifted to the formation of $\mathrm{Si}(\mathrm{OH})_{4}$. In this way, the water vapor corrosion of the TGO became more dominant, resulting in material loss and a gap formation between the silica TGO and the EBC top layer.

This behavior is described in Figure 1 showing the comparison of polished cross-sections of the microstructure after oxidation and corrosion of a model EBC system consisting of a Si bond coat and an $\mathrm{Yb}_{2} \mathrm{SiO}_{5}$ top coat. While a TGO was formed (A) after oxidation, corrosion processes with the formation of gaps at the $\mathrm{Yb}_{2} \mathrm{SiO}_{5}$-Si interface (B) were observed. 


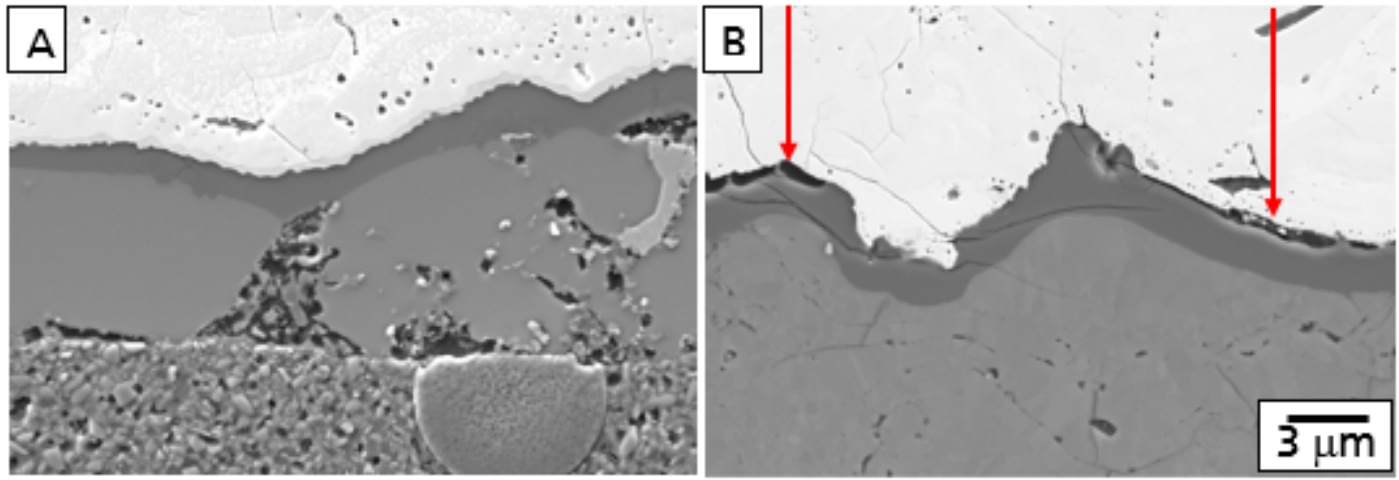

Figure 1. Polished cross-section of TGO in $\mathrm{Si}_{-} \mathrm{Y}_{2} \mathrm{SiO}_{5}$ EBC system after (A) $100 \mathrm{~h}$ oxidation at $1200{ }^{\circ} \mathrm{C}$ in air and (B) $100 \mathrm{~h}$ hot gas corrosion at $1200^{\circ} \mathrm{C}$.

\subsection{CMC Substrate Material}

The results of the high-temperature tests of the base CMC without EBC were characterized by investigation of the microstructure of the surface region. After both tests, oxidation and the burner rig, a weight gain was observed. During oxidation, a protective layer of mainly $\mathrm{SiO}_{2}$ was formed at the surface of the material, limiting the diffusion of oxygen into the material (Figure 2A). This behavior was comparable to dense monolithic $\mathrm{SiC}$. Both oxidation (weight gain) and corrosion (weight loss) were observed during the burner rig test. Caused by the water vapor corrosion of the protecting $\mathrm{SiO}_{2}$ surface layer, oxygen and water vapor were able to diffuse deeper into the material and oxidized the matrix and the fibers too (Figure 2B). As a consequence of these oxidation processes inside of the material, a higher weight gain was found after the burner rig test.
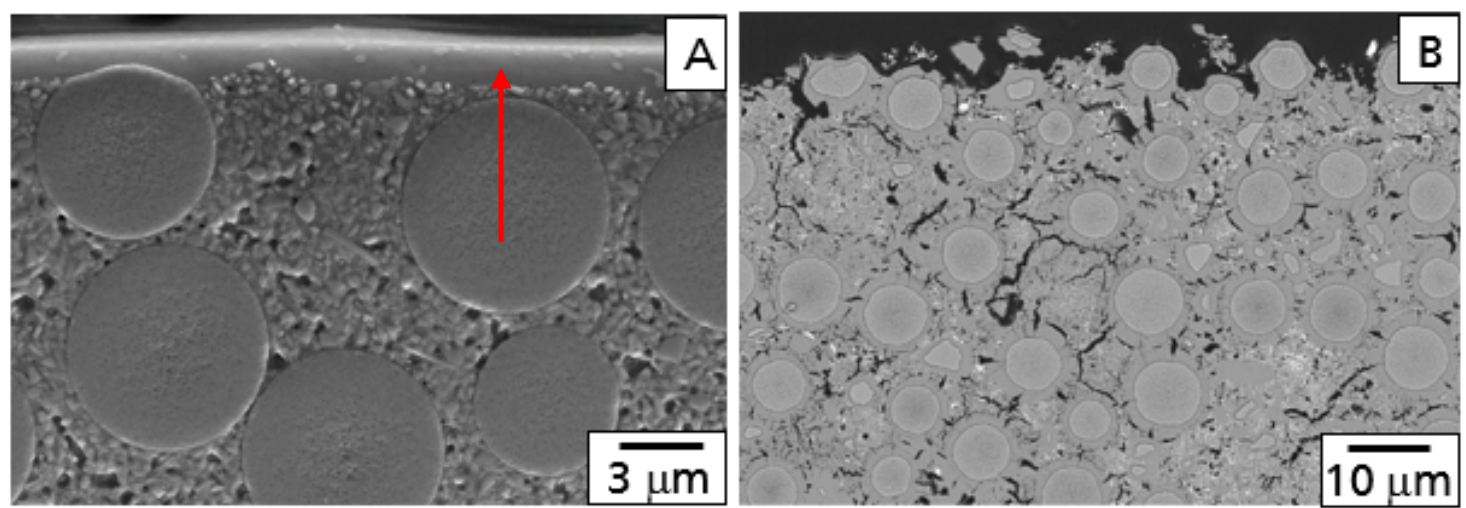

Figure 2. Microstructure of polished cross-sections of the base CMC after thermal treatment. (A) $100 \mathrm{~h}$ oxidation at $1200^{\circ} \mathrm{C}$; (B) $100 \mathrm{~h}$ burner rig test at $1200^{\circ} \mathrm{C}$.

\section{2. $\mathrm{Al}_{2} \mathrm{O}_{3}-\mathrm{YAG} E B C$ Coating System}

In the case of the material coated with $\mathrm{Al}_{2} \mathrm{O}_{3}-\mathrm{YAG}$, a weight gain was observed after both tests. The values were found to be higher in comparison to the base CMC. Two effects are assumed to be the reason; first, a low protective ability caused by the inhomogeneity of the double layer with a high amount of cracks and porosity, and second, the TGO as the rate controlling factor for oxidation based on an alumosilicate glass with a significantly higher diffusion ability in comparison to the surface oxidation layer formed during oxidation of the base CMC [25].

The microstructure of the $\mathrm{Al}_{2} \mathrm{O}_{3}-\mathrm{YAG}$ EBC coating on the $\mathrm{SiC}_{\mathrm{F}}-\mathrm{SiC}(\mathrm{N})$ composite in the coated condition is illustrated in Figure 3. 


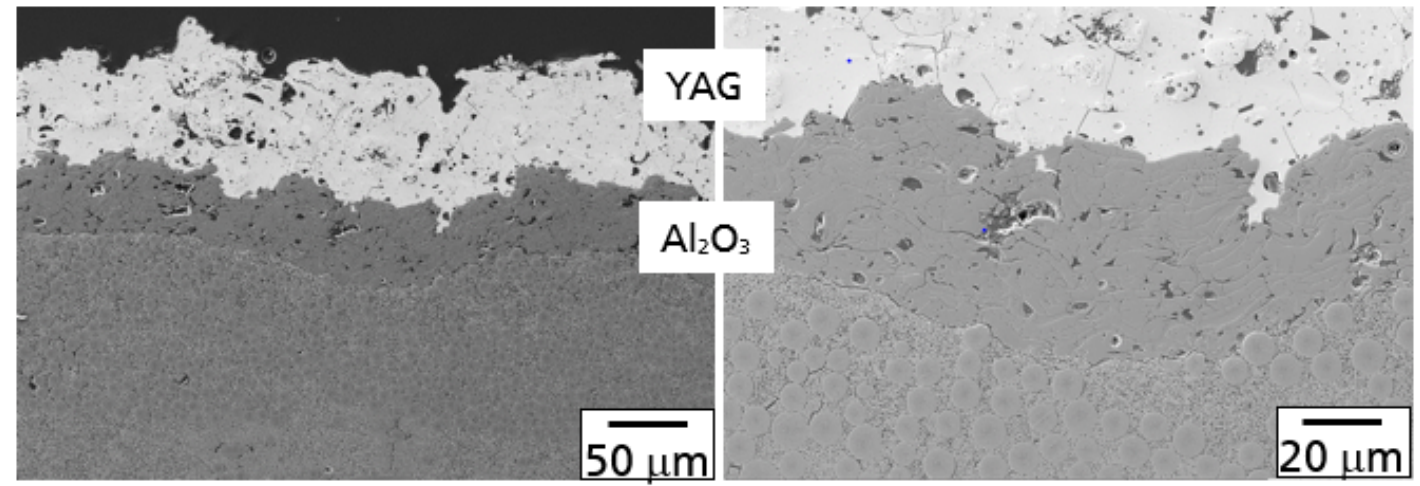

Figure 3. Microstructure of EBC consisting of $\mathrm{Al}_{2} \mathrm{O}_{3}$ bond coat and YAG top coat.

In principle, both processes, as described above, were observed after oxidation and the hot gas test. A comparison of polished cross-sections with the $\mathrm{Al}_{2} \mathrm{O}_{3} / \mathrm{YAG}$ coating is shown in Figure 4 after oxidation in air (A) and the burner rig test (B) at $1200^{\circ} \mathrm{C}$ and $100 \mathrm{~h}$.
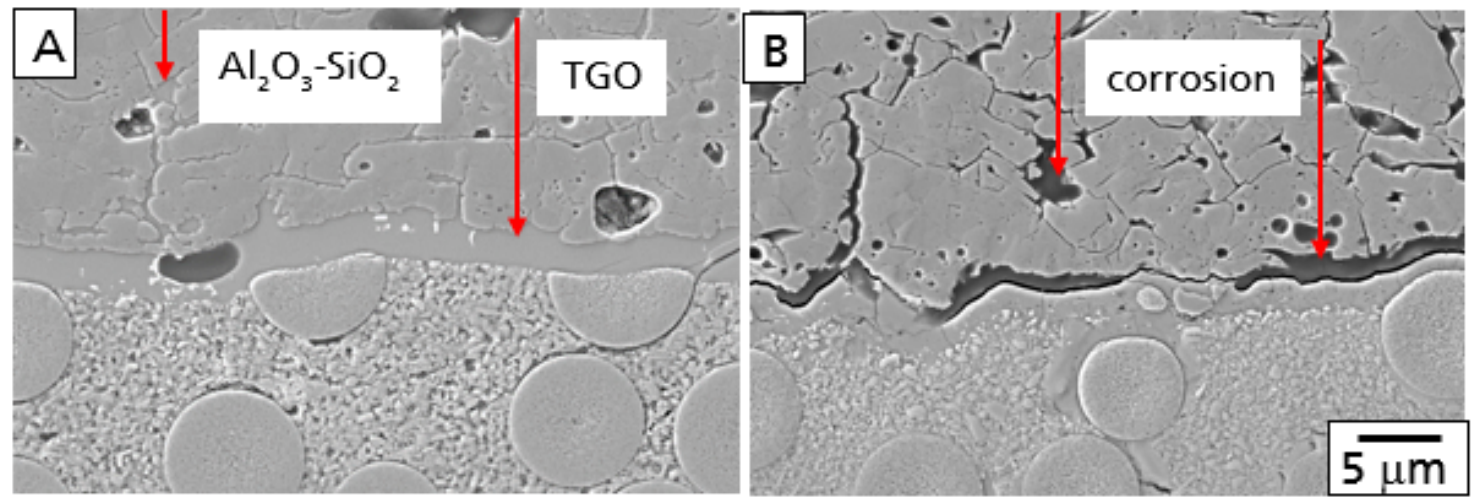

Figure 4. Comparison of microstructure in polished cross-sections of $\mathrm{SiC}_{\mathrm{F}} / \mathrm{SiC}(\mathrm{N})$ composite coated with $\mathrm{Al}_{2} \mathrm{O}_{3}$-YAG. (A) TGO formation and $\mathrm{Al}_{2} \mathrm{O}_{3}-\mathrm{SiO}_{2}$ glass in and under the alumina layer after $100 \mathrm{~h}$ oxidation at $1200{ }^{\circ} \mathrm{C}$. (B) Corrosion of TGO and grain boundary in the volume of $\mathrm{Al}_{2} \mathrm{O}_{3}$ layer after burner rig test $100 \mathrm{~h}$ and $1200^{\circ} \mathrm{C}$.

During the oxidation test, oxygen diffused through the $\mathrm{YAG} / \mathrm{Al}_{2} \mathrm{O}_{3}$ layer and oxidized the $\mathrm{SiC}$ fibers and $\mathrm{SiC}(\mathrm{N})$-matrix to $\mathrm{SiO}_{2}$. Consequently, a TGO layer at the interface of the $\mathrm{CMC}$ base material and the $\mathrm{Al}_{2} \mathrm{O}_{3}$ bond coat was formed. Furthermore, a part of the oxidation product was found in the grain boundaries and triple junctions of the $\mathrm{Al}_{2} \mathrm{O}_{3}$ bond coat. The composition of the oxidation products in both the TGO and $\mathrm{Al}_{2} \mathrm{O}_{3}$ layer was a glassy alumosilicate (Figure $4 \mathrm{~A}$ ).

As described above, corrosion processes were observed additionally after the burner rig test (Figure 4B). The alumosilicate glass in both the TGO and the grain boundaries and triple junctions were found to be corroded, forming small pores and voids in the $\mathrm{Al}_{2} \mathrm{O}_{3}$ bond coat and gaps between the top of the TGO and the bond coat. With increasing time, both corrosion processes will damage the EBC system. Especially, the corrosion of the TGO will form large defects, finally leading to failure of the EBC. The smaller pores and voids in the alumina bond coat, however, are much more stable from a mechanical point of view.

Notwithstanding other damage mechanisms, this behavior opens an idea to the enhance high-temperature stability of the EBC in principle. By the shifting of the oxidation processes from the interface of the TGO into the volume of the bond coat, it should be possible to decelerate the TGO formation. Furthermore, the damage mechanism in the TGO (crystallization processes and corrosion) could be avoided, and only smaller corrosion defects in the bond coat should be observed. 


\section{3. $\mathrm{Si}-\mathrm{Yb}_{2} \mathrm{Si}_{2} \mathrm{O}_{7} / \mathrm{SiC}-\mathrm{Yb}_{2} \mathrm{SiO}_{5}$ EBC Coating System}

This mechanism described above was considered in the design of a three-layer coating system investigated next with a silicon bond coat, an intermediate layer consisting of $\mathrm{Yb}_{2} \mathrm{Si}_{2} \mathrm{O}_{7}$ with $\mathrm{SiC}$ particles, and $\mathrm{Yb}_{2} \mathrm{SiO}_{5}$ as the top coat featured by a superior hot gas stability. The microstructure of this EBC is demonstrated in Figure 5. Few microcracks were observed in the $\mathrm{Yb}_{2} \mathrm{SiO}_{5}$ top layer, probably as a consequence of the CTE mismatch between the top and intermediate layer $\left(\mathrm{CTE} \mathrm{Yb}_{2} \mathrm{Si}_{2} \mathrm{O}_{7}\right.$ $4.2 \times 10^{-6} \mathrm{~K}^{-1}$; $\mathrm{CTE} \mathrm{Yb}_{2} \mathrm{SiO}_{5} 6.8 \times 10^{-6} \mathrm{~K}^{-1}$ ).
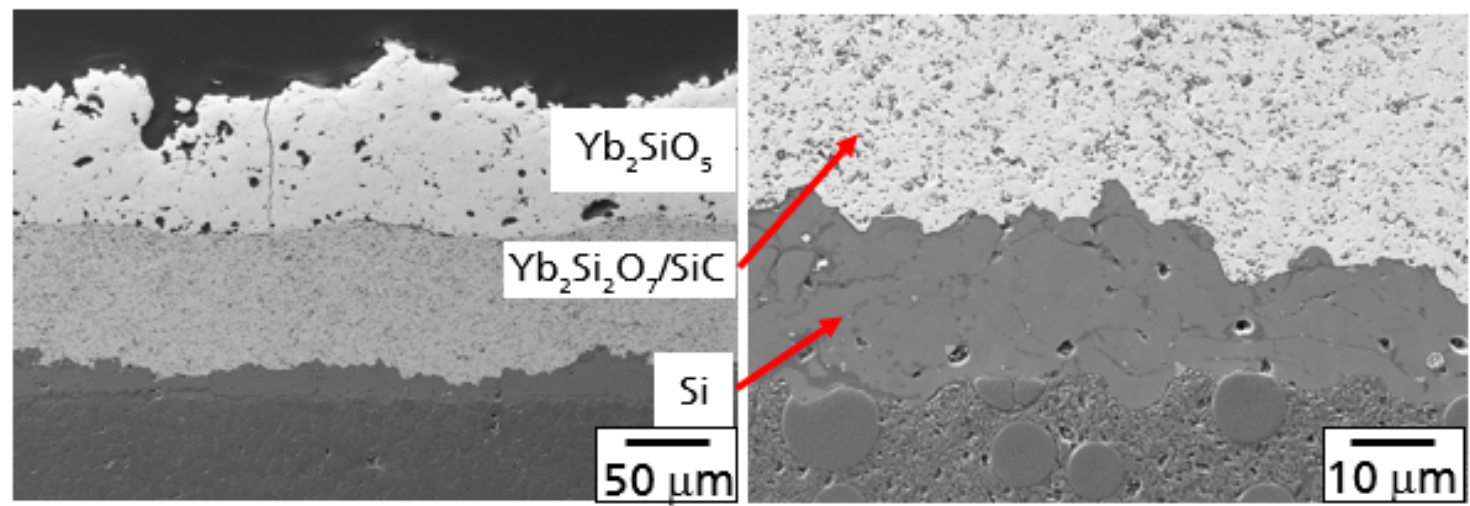

Figure 5. Polished cross-section of EBC layer system with $\mathrm{Si}$ bond coat, $\mathrm{Yb}_{2} \mathrm{Si}_{2} \mathrm{O}_{7} / \mathrm{SiC}$, and $\mathrm{Yb}_{2} \mathrm{SiO}_{5}$ layer fabricated by atmospheric plasma spaying ( $\mathrm{Si}$ ) and suspension plasma spraying $\left(\mathrm{Yb}_{2} \mathrm{Si}_{2} \mathrm{O}_{7} / \mathrm{SiC}, \mathrm{Yb}_{2} \mathrm{SiO}_{5}\right)$.

In comparison to the other materials investigated, only a small weight gain was measured after both tests at elevated temperatures. This should be caused by a protecting function, especially of the $\mathrm{Yb}_{2} \mathrm{Si}_{2} \mathrm{O}_{7} / \mathrm{SiC}$ layer. Oxygen diffusion through the EBC layers and the oxidation reaction in the $\mathrm{Yb}_{2} \mathrm{Si}_{2} \mathrm{O}_{7} / \mathrm{SiC}$ layer were found to be the main processes observed after the oxidation test. The SiC particles in the intermediate layer were oxidized, consequently leading to the formation of a $\mathrm{SiO}_{2} \mathrm{scale}$ on the $\mathrm{SiC}$ particles. The diffusion of oxygen through this $\mathrm{SiO}_{2}$-based layer controlled the oxidation process of the whole system during the testing time performed. A typical example for the mechanism is demonstrated in Figure $6 \mathrm{~A}$, presenting a polished cross-section at the interface of the $\mathrm{Yb}_{2} \mathrm{SiO}_{5}$ top coat and the $\mathrm{Yb}_{2} \mathrm{Si}_{2} \mathrm{O}_{7} / \mathrm{SiC}$ intermediate layer.

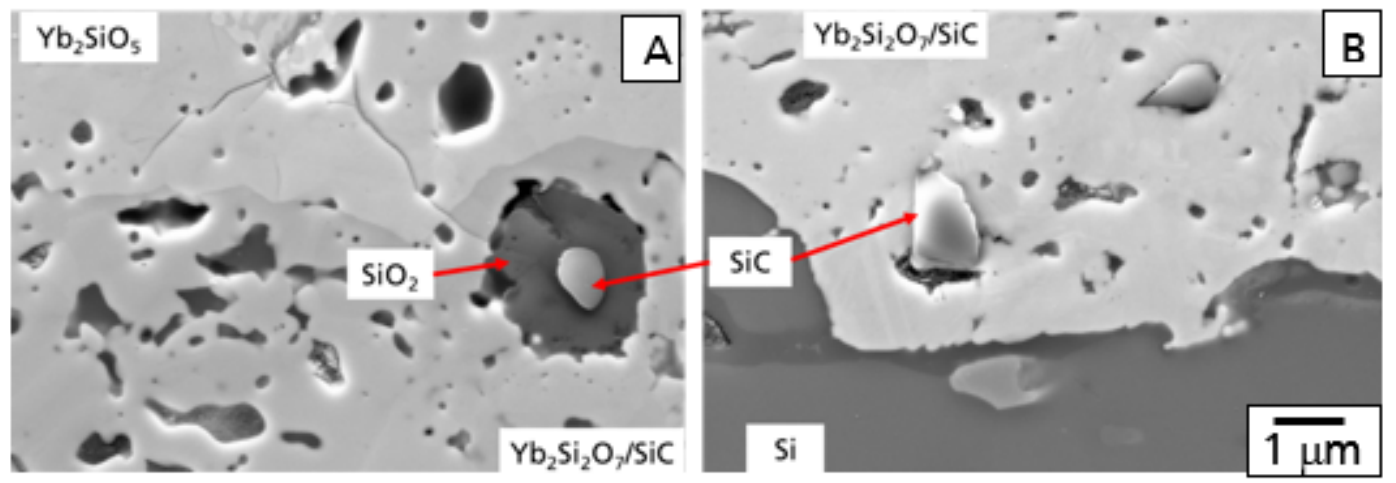

Figure 6. Polished cross-section of $\mathrm{Si}-\mathrm{Yb}_{2} \mathrm{Si}_{2} \mathrm{O}_{7} / \mathrm{SiC}-\mathrm{Yb}_{2} \mathrm{SiO}_{5} \mathrm{EBC}$ coating system. SiC particle in $\mathrm{Yb}_{2} \mathrm{Si}_{2} \mathrm{O}_{7}$ layer at interfaces $(\mathbf{A}) \mathrm{Yb}_{2} \mathrm{SiO}_{5}-\mathrm{Yb}_{2} \mathrm{Si}_{2} \mathrm{O}_{7} / \mathrm{SiC}$ and (B) $\mathrm{Yb}_{2} \mathrm{Si}_{2} \mathrm{O}_{7} / \mathrm{SiC}-\mathrm{Si}$ after oxidation for $100 \mathrm{~h}$ and $1200{ }^{\circ} \mathrm{C}$.

The SiC particles in this layer operated as a getter for the diffusion of oxygen, preventing further oxygen at diffusing deeper into the material. This effect is illustrated in Figure 6B with the 
microstructure at the interface between the $\mathrm{Si}$ bond coat and the $\mathrm{Yb}_{2} \mathrm{Si}_{2} \mathrm{O}_{7} / \mathrm{SiC}$ intermediate layer. As the diffusion of oxygen reacted with $\mathrm{SiC}$ particles in the upper region of this layer, no oxidation processes were observed in this area. The SiC grains did not show an oxidation layer. Furthermore, the formation of a TGO was not observed. Similar results on the graded oxidation of SiC-particles have been reported in context of the mechanical self-healing ability of $\mathrm{Yb}_{2} \mathrm{Si}_{2} \mathrm{O}_{7} / \mathrm{SiC}$ composites $[26,27]$.

In Figure 7, the microstructure of this EBC system is shown after the $100 \mathrm{~h}$ hot gas corrosion test at $120{ }^{\circ} \mathrm{C}$. Although some additional cracks formed, the EBC coating is still intact, protecting the CMC from the direct hot gas corrosion attack (Figure 7A).
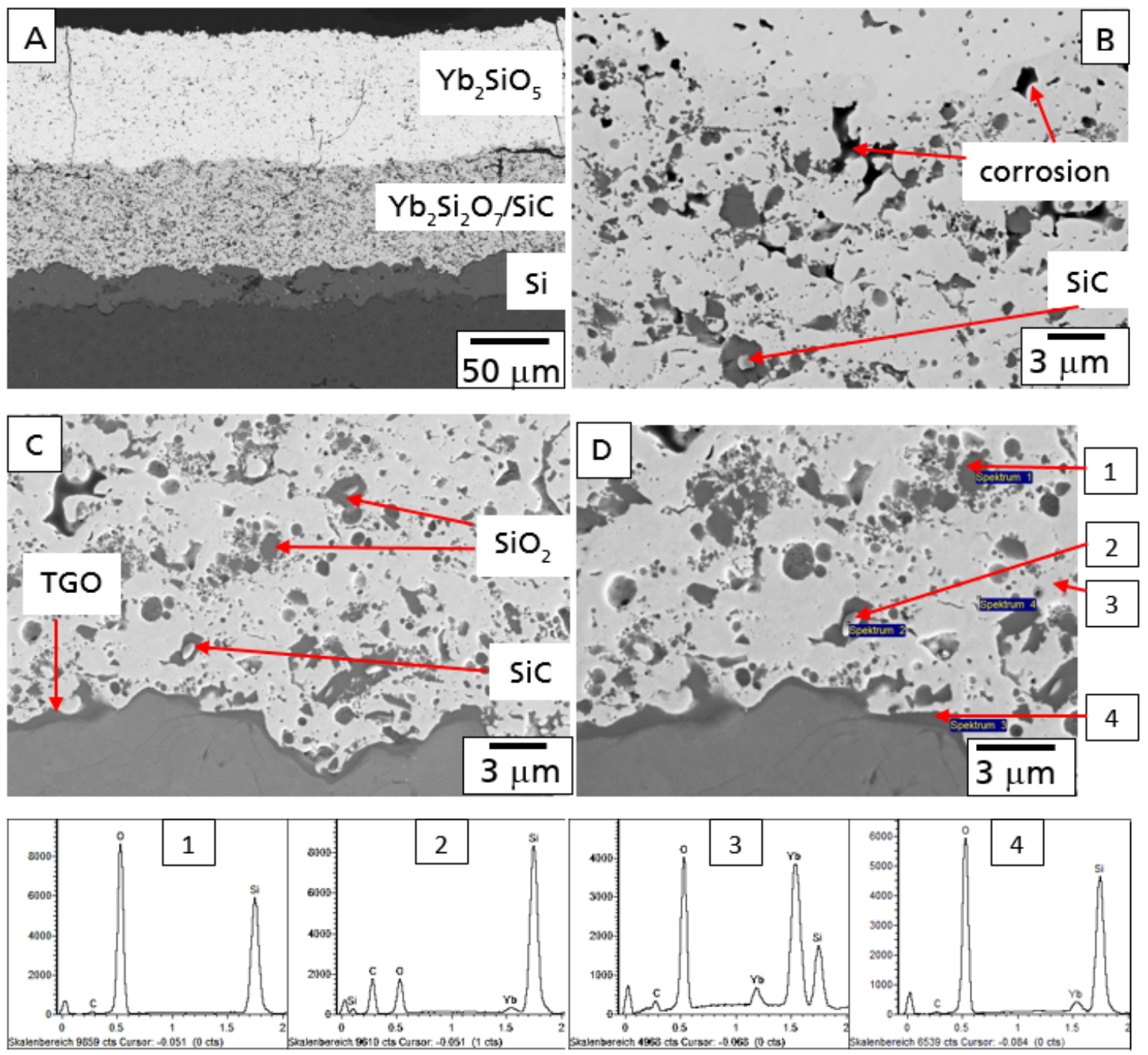

Figure 7. Polished cross-section of $\mathrm{SiC}_{\mathrm{F}} / \mathrm{SiC}(\mathrm{N})$ composite with three-layer $\mathrm{EBC}$ $\left(\mathrm{Si}_{-} \mathrm{Yb}_{2} \mathrm{Si}_{2} \mathrm{O}_{2} / \mathrm{SiC}-\mathrm{Yb}_{2} \mathrm{SiO}_{5}\right)$ after $100 \mathrm{~h}$ hot gas test $(\mathrm{A})$ at $1200{ }^{\circ} \mathrm{C}$, overview; $(\mathbf{B})$ at the interface to the $\mathrm{Yb}_{2} \mathrm{SiO}_{5}$ top coat and the $\mathrm{Yb}_{2} \mathrm{Si}_{2} \mathrm{O}_{7} / \mathrm{SiC}$ interlayer, and $(\mathbf{C})$ at the interface between the $\mathrm{Yb}_{2} \mathrm{Si}_{2} \mathrm{O}_{7} / \mathrm{SiC}$ interlayer and the Si bond coat; energy-dispersive X-ray spectroscopy (EDX) analysis of different phases in the microstructure, analysis locations demonstrated in (D).

In comparison to the oxidation test, stronger oxidation processes were observed in the $\mathrm{Yb}_{2} \mathrm{Si}_{2} \mathrm{O}_{7} / \mathrm{SiC}$ layer after the test in hot gas conditions. A higher amount of oxidants reached and oxidized the SiC particles in the intermediate layer of the EBC coating system as a consequence of additional water vapor permeation. In agreement to the literature [28,29], water vapor was found to be the dominant oxidant caused by the significantly higher solubility of $\mathrm{H}_{2} \mathrm{O}$ in $\mathrm{SiO}_{2}$. A second reasonable possibility is the formation of interconnected open splat boundaries in the $\mathrm{Yb}$-silicate layer [26]. Further investigation 
has to be performed in this field. The $\mathrm{SiC}$ particles were found to be oxidized to $\mathrm{SiO}_{2}$ up to the bottom of the $\mathrm{Yb}_{2} \mathrm{Si}_{2} \mathrm{O}_{7} / \mathrm{SiC}$ layer. As a part of the oxidant reached the Si-bond coat the TGO layer started to grow (Figure 7C). Results of EDX analysis of microstructural details of this part are presented in Figure 7.

Additional processes were observed in the top region of the $\mathrm{Yb}_{2} \mathrm{Si}_{2} \mathrm{O}_{7} / \mathrm{SiC}$ layer. Some of the $\mathrm{SiO}_{2}$ areas formed by the oxidation of the $\mathrm{SiC}$ particles were found to be corroded by water vapor, finally leading to the formation of pores in the top region of the intermediate layer (Figure 7B).

\section{Discussion}

As already mentioned above, the penetration of oxidants into the EBC system and the following formation of a TGO cannot be prevented completely. However, with purposeful design of the EBC layer system, the transport processes and the following oxidation processes can be influenced. The first possibility should be the reduction of the transport processes for $\mathrm{O}_{2}$ and $\mathrm{H}_{2} \mathrm{O}$. Coatings with a lower oxygen diffusion coefficient and water vapor solubility are reasonable trends for material development.

In the present study, the following oxidation and corrosion processes were modified. With the introduction of oxidable particles into an intermediate layer, it was possible to shift the oxidation processes from the interface between the $\mathrm{Si}$ bond coat and the $\mathrm{Yb}$-silicate top coat to a volume in the intermediate layer. The processes occurring during oxidation and corrosion are schematically described in Figure 8.

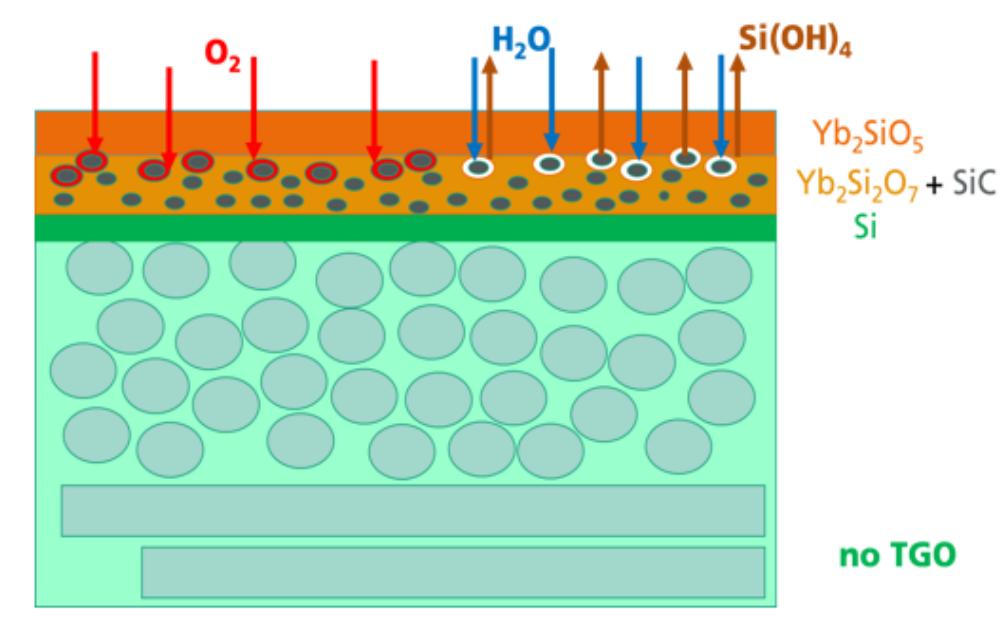

Figure 8. Schematic diagram of the oxidation and corrosion mechanism of $\mathrm{SiC}_{\mathrm{F}} / \mathrm{SiC}(\mathrm{N})$ composite with three-layer EBC system.

Independent of the thermal treatment, oxidation, or hot gas corrosion, the transport of oxidants and the following oxidation processes in the EBC system were found to be the first processes in the system. The penetrated $\mathrm{O}_{2}$ and $\mathrm{H}_{2} \mathrm{O}$ reacted with the $\mathrm{SiC}$, resulting in the formation of a $\mathrm{SiO}_{2}$-based shell surrounding the $\mathrm{SiC}$ particles. In this way, the $\mathrm{SiC}$ particles served as a getter for the further transport of oxidants into deeper regions of the whole system. As the oxidants could not reach the Si bond coat, the formation of the TGO was prevented. In a hot gas atmosphere with increased water vapor pressure and high gas velocity, corrosion processes were observed. The water vapor penetrated this region and reacted with the $\mathrm{SiO}_{2}$ at the surface of the $\mathrm{SiC}$ particles and formed $\mathrm{Si}(\mathrm{OH})_{4}$. $\mathrm{A} \mathrm{Si}(\mathrm{OH})_{4}$ gradient developed as a consequence of the high hot gas velocity outside, which was a driving force of the outward transport and evaporation of the $\mathrm{Si}(\mathrm{OH})_{4}$. Small pores were found to be the result of the corrosion process.

The beneficial gettering function of the SiC particulate will be a temporary effect only. After longer oxidation time or at higher temperatures, the $\mathrm{SiC}$ particles will be consumed and oxygen will reach the silicon bond coat to form the TGO. However, with the incorporation of the SiC particles, to 
be oxidized during operation in hot gas atmosphere, the EBC system could be temporary stabilized. With the delayed formation of the TGO, their resulting damage mechanisms, cracking as a result of stresses by crystallization and phase transition processes and the gap formation caused by corrosion material loss, started at later application times. A very beneficial effect in terms of long-term stability and lifetime can only be achieved by simultaneous improvement of the oxygen and $\mathrm{H}_{2} \mathrm{O}$ permeation behavior of the whole EBC layer system. The lower the transport of the oxidants into the material, the longer the gettering function of the $\mathrm{SiC}$ particles can be used. Further studies have to be performed to optimize the EBC system regarding composition and microstructure with special focus on the transport mechanisms during service in hot gas environments.

Author Contributions: H.K. conceptualized the idea; H.K., K.S. and W.K. developed the coating; K.S. and W.K. performed the experiments and analyzed data; H.K. supervised the project and acquired funding; H.K. prepared the manuscript; K.S. and W.K. contributed in editing and submission. All authors have read and agreed to the published version of the manuscript.

Funding: This research was funded by the German Federal Ministry for Education and Research, grant number 03EK3544C and Fraunhofer Funding MAVO CMC engine.

Acknowledgments: The authors gratefully thank B. Gronde and F.L. Toma for support in plasma spraying technology.

Conflicts of Interest: The authors declare no conflict of interest.

\section{References}

1. Endo, Y.; Tsuchiya, T.; Furuse, Y. Corrosion behavior of ceramics for gas turbines application, silicon based structural ceramics. Ceram. Trans. 1994, 42, 319-326.

2. Opila, E.J.; Hann, R.E. Paralinear Oxidation of CVD SiC in water vapor. J. Am. Ceram. Soc. 1997, 80, 197-205. [CrossRef]

3. Yuri, I.; Hisamatsu, T. Recession Rate Prediction for Ceramic Materials in Combustion Gas Flow. In Proceedings of the ASME Turbo Expo 2003, Atlanta, GA, USA, 16-19 June 2003.

4. Filsinger, D.; Schulz, A.; Wittig, S.; Taut, C.; Klemm, H.; Wötting, G. Model Combustor to Assess the Oxidation Behavior of Ceramic Materials under Real Engine Conditions. In Proceedings of the ASME Turbo Expo ‘99, Indianapolis, Indianapolis, IN, USA, 7-10 June 1999.

5. More, L.K.; Tortorelli, P.F.; Ferber, M.K.; Keiser, L.R. Observations of accelerated silicon carbide recession by oxidation at high water-vapor pressures. J. Am. Ceram. Soc. 2000, 83, 211-223. [CrossRef]

6. Klemm, H.; Schubert, C.; Taut, C.; Schulz, A.; Wötting, G. Corrosion of Non-Oxide Silicon-Based Ceramics in a Gas Turbine Environment. In Proceedings of the 7th Symposium on Ceramic Materials \& Components for Engines, 2000, Weinheim, Germany, 29 March 2001; WILEY-VCH Verlag: Weinheim, Germany, 2001; pp. 153-156.

7. Lee, K.N.; Fritze, H.; Ogura, Y. Coatings for engineering ceramics. In Progress in Ceramic Gas Turbine Development; van Roode, M., Ferber, M., Richerson, D.W., Eds.; ASME Press: New York, NY, USA, 2003; Volume 2, pp. 641-664.

8. Lee, K.N. Environmental barrier coatings for CMCs. In Ceramic Matrix Composites; Bansal, N.P., Lamon, J., Eds.; Wiley: New York, NY, USA, 2015; pp. 430-451.

9. Lee, K.N. Current status of environmental barrier coatings for Si-based ceramics. Surf. Coat. Technol. 2000, 133, 1-7. [CrossRef]

10. Lee, K.N.; Fox, D.S.; Bansal, N.P. Rare earth silicate environmental barrier coatings for SiC/SiC composites and Si3N4 ceramics. J. Eur. Ceram. Soc. 2005, 25, 1705-1715. [CrossRef]

11. Fritsch, M. Heißgaskorrosion keramischer Werkstoffe in H2O-haltigen Rauchgasatmosphären. In Dissertationsschrift, TU Dresden; Fraunhofer IRB Verlag: Stuttgart, Germany, 2007; ISBN 978-3-8167-7588-1.

12. Klemm, H. Silicon nitride for high-temperature applications. J. Am. Ceram. Soc. 2010, 93, 1501-1522. [CrossRef]

13. Ueno, S.; Ohji, T.; Lin, H.T. Recession behavior of Yb2Si2O7 phase under high speed steam jet at high temperatures. Corros. Sci. 2008, 50, 178-182. [CrossRef] 
14. Yuri, I.; Hisamatsu, T.; Ueno, S.; Ohji, T. Exposure test results of Lu2Si2O7 in combustion gas flow at high temperature and high speed. Jpn. Soc. Mech. Eng. 2001, 44, 520-527.

15. Hong, Z.; Cheng, L.; Zhang, L.; Wang, Y. Water vapor corrosion behavior of scandium silicates at $1400{ }^{\circ} \mathrm{C}$. J. Am. Ceram. Soc. 2009, 92, 193-196. [CrossRef]

16. Richards, B.T.; Young, K.A.; de Francqueville, F.; Sehr, S.; Begley, M.R.; Wadley, H.N.G. Response of ytterbium disilicate-silicon environmental barrier coatings to thermal cycling in water vapor. Acta. Mater. 2016, 106, 1-14. [CrossRef]

17. Bakan, E.; Sohn, Y.J.; Kunz, W.; Klemm, H.; Vaßen, R. Effect of processing on high-velocity water vapor recession behavior of Yb-silicate environmental barrier coatings. J. Europ. Ceram. Soc. 2019, 39, 1507-1513. [CrossRef]

18. Lee, K.N.; Fox, D.S.; Eldridge, J.I.; Zhu, D.; Robinson, R.C.; Bansal, N.P.; Miller, R.A. Upper temperature limit of environmental barrier coatings based on mullite and BSAS. J. Am. Ceram. Soc. 2003, 86, 1299-1306. [CrossRef]

19. Lee, K.N. Yb2Si2O7 Environmental barrier coatings with reduced bond coat oxidation rates via chemical modifications for long life. J. Am. Ceram. Soc. 2019, 102, 1507-1521. [CrossRef]

20. Xu, Y.; Hu, X.; Xu, F.; Li, K. Rare earth silicate environmental barrier coatings: Present status and prospective. Ceram. Int. 2017, 43, 5847-5855. [CrossRef]

21. Zhong, X.; Niu, Y.; Li, H.; Zhou, H.; Dong, S.; Zheng, X.; Ding, C.; Sun, J. Thermal shock resistance of tri-layer $\mathrm{Yb} 2 \mathrm{SiO} 5 / \mathrm{Yb} 2 \mathrm{Si} 2 \mathrm{O} 7 / \mathrm{Si}$ coating for $\mathrm{SiC}$ and SiC-matrix composites. J. Am. Ceram. Soc. 2018, 101, 4743-4752. [CrossRef]

22. Lu, Y.; Luo, L.; Liu, J.; Zhu, C.; Wang, Y. Failure mechanism associated with the thermally grown silica scale in environmental barrier coated C/SiC composites. J. Am. Ceram. Soc. 2016, 99, 2713-2719. [CrossRef]

23. Klemm, H.; Herrmann, M.; Schubert, C. High temperature oxidation and corrosion of silicon-based nonoxide ceramics. J. Eng. Gas. Turbines Power 2000, 122, 13-18. [CrossRef]

24. Schönfeld, K.; Klemm, H. Interaction of fiber matrix bonding in $\mathrm{SiC} / \mathrm{SiC}$ ceramic matrix composites. J. Europ. Ceram. Soc. 2019, 39, 3557-3565. [CrossRef]

25. Courtright, E.L. Engineering property limitations of structural ceramics and ceramic composites above $1600{ }^{\circ}$ C. Ceram. Eng. Sci. Proc. 1991, 12, 1725-1744.

26. Kunz, W. Entwicklung selbstheilender Materialien zum Korrosionsschutz für Keramiken in Hochtemperaturanwendungen. In Dissertationsschrift, TU Dresden; Fraunhofer: Munich, Germany, 2019; ISBN 978-3-8396-1507-2.

27. Kunz, W.; Klemm, H. Self-healing EBC material for gas turbine applications. Advances in high temperature ceramic matrix composites and materials for sustainable development. Ceram. Trans. 2018, 263, 173-185.

28. Deal, B.E.; Grove, A.S. General relationship for the thermal oxidation of silicon. J. Appl. Phys. 1965, 36, 3770-3778. [CrossRef]

29. Opila, E.J. Variation of the oxidation rate of silicon carbide with water-vapor pressure. J. Am. Ceram. Soc. 1999, 82, 625-636. [CrossRef]

(C) 2019 by the authors. Licensee MDPI, Basel, Switzerland. This article is an open access article distributed under the terms and conditions of the Creative Commons Attribution (CC BY) license (http://creativecommons.org/licenses/by/4.0/). 